\title{
Effect of protein and carbohydrate feed concentrations on the growth and composition of black soldier fly (Hermetia illucens) larvae
}

\author{
by Beniers, J.J.A. and Graham, R.I.
}

Copyright, Publisher and Additional Information: This is the authors' accepted manuscript. The final published version (version of record) is available online via Wageningen Academic Publishers

Please refer to any applicable terms of use of the publisher.

DOI: https://doi.org/10.3920/JIFF2018.0001 
Effect of protein and carbohydrate feed concentrations on the growth and composition of black soldier fly (Hermetia illucens) larvae.

J. J. A. Beniers ${ }^{1}$, R. I. Graham ${ }^{2}$

${ }^{1}$ Animal Science Department, Université Laval, Quebec City, Canada

${ }^{2}$ Crop and Environment Sciences, Harper Adams University, Edgmond, Shropshire TF2 8NB, United Kingdom

Corresponding author: julianbeniers@ hotmail.com

\begin{abstract}
Black soldier flies (Hermetia illucens) can be used for a wide range of applications, from screening their anti-microbial properties, entomophagy through to waste management. Although the use of black soldier flies for these purposes has been widely studied, mass-rearing black soldier flies is still in the preliminary phase. This study focussed on the nutritional composition of black soldier fly larvae over the course of their life history, and the impact of manipulating dietary protein and carbohydrate on the growth and composition (protein and fat) of the larvae. Larvae were collected every $24 \mathrm{~h}$ over the course of this life-stage to test for differences in composition. To test the effect of dietary protein and carbohydrate differences, larvae were fed 25 diets with varying concentrations of protein and carbohydrates. Overall, the composition of larvae changed very little over their life history, with the higher concentration of protein mostly observed in the earlier instars of the larvae. The pre-pupal stage reduced the fresh and dry weight of the larvae, whereas the ash concentration was very stable throughout their life history. Both dietary protein and dietary carbohydrate had a significant effect on the fresh and dry weight of the larvae, but dietary protein was a stronger indicator of larval fresh and dry weight than dietary carbohydrate. Larval composition was also influenced by the feedtype, with heavier larvae producing significantly more fat than the lighter ones.
\end{abstract}

Keywords: dietary requirements, entomophagy, stratiomyidae 


\section{Introduction}

Entomophagy might be able to solve some of the challenges facing our planet. One of these problems is the 805 million undernourished people in the world. Insects are rich in minerals and vitamins, and it has been proposed that they would be able to provide a healthy alternative food source (Gahukar, 2011; Nadeau et al., 2015). Nadeau et al. (2015) suggest that if 15,586 $-92,976 \mathrm{ha}^{2}$ was devoted to insect rearing, it could reduce or eliminate this problem. Another problem to which entomophagy could offer a solution is overfishing, with populations of fish such as the Atlantic Cod (Gadus morhua) reportedly at $20 \%$ of their original population (Eriksson and Andersson, 2010). Most of these fish are either used for human consumption or to feed other fish/animals in the aquaculture/agriculture industries. Insects could replace between 25 and $33 \%$ of the fish meal in the diet of fish in the aquaculture industry (Burtle et al., 2012; Cummins et al., 2017; Kroeckel et al., 2012). This percentage could be increased further by promoting chitinase activity or chitinolytic bacteria that would allow the fish to better digest the chitin, or the potential insect-feed had a higher concentration of omega-3 fatty acids (Barroso et al., 2017; Kroeckel et al., 2012; St-Hilaire et al., 2007).

One of the insect species often used in the aquaculture industry is the black soldier fly (Hermetia illucens). This insect has been shown to have a wide variety of properties that can be beneficial. They have been used for forensic entomology, during dry post-decay stages in more tropical areas (Lord et al., 1994; Pujol-Luz et al., 2008). The black soldier fly also shows anti-microbial properties, producing hexanedioic acid, methanol and antimicrobial peptides that have been proven to effectively prohibit the growth/proliferation of both gram-positive and -negative bacteria and fungus (Choi et al., 2012; Choi and Jiang, 2014; Elhag et al., 2017; Park et al., 2014). Lastly, the black soldier fly can also be very well applied as part of a waste management program. For example, studies have shown that black soldier fly larvae can reduce between 50 and $78 \%$ of the dry matter of manure (Lalander et al., 2013; Sheppard et al., 1994; Zhou et al., 2013).

To date, the majority of studies on the black soldier fly have focused on the application of the larvae, rather than on finding an optimal rearing strategy. Previous studies have been executed on abiotic factors, such as temperature and humidity, and dietary requirements. Cammack and Tomberlin (2017) and Oonincx et al. (2015) have indicated that the black soldier fly larvae are a good candidate for converting lower value feed sources. However, these studies are often comparing different feed sources, such as 'Fish Renderings' with 'Swine Liver' (Cammack and Tomberlin, 2017). This different composition most likely has an influence on the growth of the larvae. For example, mealworms (Tenebrio molitor) have varying growth rates depending on the particular amino acids present in the feed(Davis, 1975).

In this study, the impact of various protein and carbohydrate concentrations on the growth of black soldier fly larvae was examined. To exclude the above-mentioned difference in feed compositions, a single base diet was enriched with the two macronutrients. It is hypothesized that the dietary protein concentration contributes to the growth of the larvae, and the carbohydrate contributes to the fat production of the larvae.

\section{Material \& Methods}

\section{Experiment 1: Composition over the course of the larval stage}

This first experiment was executed to examine protein and fat accumulation in black soldier fly over the course of their larval stage. To examine this, 2,500 larvae, with an average weight of $15 \mathrm{mg}$ (commercially purchased from Swell Reptiles, UK), were placed on a chickenfeed-based substrate $(70 \%$ moisture), which wet-weight is composed of $17.5 \%$ protein, $48.8 \%$ 
carbohydrates, $5.9 \%$ fat, $3.93 \%$ calcium, $0.4 \%$ phosphorus and $0.14 \%$ sodium. The larvae were placed in a climate chamber (Sanyo MLR350; Sanyo, UK) at $28^{\circ} \mathrm{C}$ without any light. Each subsequent day, at least $5 \mathrm{~g}$ of larvae were collected from the sample and fed additional chickenfeed, until $25 \%$ of the larvae had reached pre-pupal stage, upon which only pre-pupal stage larvae were collected and the remaining larvae were discarded. The collected larvae were washed to dispose of any remaining substrate or faecal matter. Afterwards, the larvae were euthanized in the freezer $\left(-20^{\circ} \mathrm{C}\right)$ and stored until needed for chemical analysis.

\section{Experiment 2: Rearing larvae at varying protein and carbohydrate dietary ratios}

To determine the influence of dietary protein and carbohydrate on black soldier fly larvae, the following experiment was undertaken. A total of 12,500 insects were used in this experiment. Each cup had $11.8 \mathrm{~g}$ of the chickenfeed diet, with $15 \pm 3 \mathrm{~mL}$ of tap water and the additional protein and carbohydrate depending on the treatment. Protein ratio was enhanced by Promax Maxinutrition Max Protein shake powder, which is composed of $71.4 \%$ protein, 5.9\% carbohydrate and $5.7 \%$ fat on wet-weight basis. The carbohydrate ratio was enhanced by Polenta valsugana which was composed of $7.2 \%$ protein, $77.4 \%$ carbohydrate and $1.2 \%$ fat on wet-weight basis. Each treatment was replicated ten times. There were four and five concentrations of added protein or carbohydrates, $0 \mathrm{~g}, 0.7 \mathrm{~g}, 1.4 \mathrm{~g}$ and $2.1 \mathrm{~g} ; 0 \mathrm{~g}, 0.97 \mathrm{~g}, 1.94 \mathrm{~g}$, $2.91 \mathrm{~g}$ and $3.88 \mathrm{~g}$, respectively (Table 1 ). Each of these cups included 50 larvae and was placed in a Sanyo MLR350 climate chamber at $28^{\circ} \mathrm{C}$ without any light. Any cup that had been subjected to a drier environment will be discarded from the dataset. The larvae were harvested after eight days in the climate chamber and stored at $-20^{\circ} \mathrm{C}$ until required for chemical analysis.

Table 1: The wet weight composition of the diets used for experiment 2, each additional level of protein adds $0.5 \mathrm{~g}$ of protein and each level of carbohydrate adds $0.75 \mathrm{~g}$ of carbohydrates. The first row represents the composition of the chickenfeed.

\begin{tabular}{rr|rrr}
$\begin{array}{l}\text { Protein } \\
\text { Treatment }\end{array}$ & $\begin{array}{l}\text { Carbohydrate } \\
\text { Treatment }\end{array}$ & & & \\
Protein $(\mathrm{g})$ & Carbohydrate $(\mathrm{g})$ & Fat $(\mathrm{g})$ \\
\hline 1 & 1 & 2.06 & 5.75 & 0.70 \\
1 & 2 & 2.13 & 6.50 & 0.71 \\
1 & 3 & 2.20 & 7.25 & 0.72 \\
1 & 4 & 2.27 & 8.00 & 0.73 \\
1 & 5 & 2.34 & 8.75 & 0.74 \\
\hline 2 & 1 & 2.56 & 5.79 & 0.74 \\
2 & 2 & 2.63 & 6.54 & 0.75 \\
2 & 3 & 2.70 & 7.29 & 0.76 \\
2 & 4 & 2.77 & 8.05 & 0.77 \\
2 & 5 & 2.84 & 8.80 & 0.78 \\
\hline 3 & 1 & 3.06 & 5.83 & 0.78 \\
3 & 2 & 3.13 & 6.58 & 0.79 \\
3 & 3 & 3.20 & 7.34 & 0.80 \\
3 & 4 & 3.27 & 8.09 & 0.81 \\
3 & 5 & 3.34 & 8.84 & 0.82 \\
\hline 4 & 1 & 3.56 & 5.88 & 0.82 \\
4 & 2 & 3.63 & 6.63 & 0.83
\end{tabular}




\begin{tabular}{ll|lll}
4 & 3 & 3.70 & 7.38 & 0.84 \\
4 & 4 & 3.77 & 8.13 & 0.85 \\
4 & 5 & 3.84 & 8.88 & 0.86 \\
\hline
\end{tabular}

\section{Chemical analysis}

All collected larval samples were subject to drying, by being placed at $80^{\circ} \mathrm{C}$ for $2-3$ days, as similarly executed in protocol 950.46 (AOAC, 1990). Afterwards all the larvae of experiment 1 were ground, whereas only half of the repetitions from experiment 2 . Three chemical analysis protocols were applied: the leco, soxhlet and ashing. The leco method (FP-528) allows for protein analysis by combusting the sample of approximately $0.15 \mathrm{~g}$ and measuring the concentration of nitrogen (AOAC 976.05 as cited by (Surendra et al., 2016), this can be converted to a percentage of protein by multiplying by 4.76, as suggested by Janssen et al. (2017). The soxhlet method was used to analyse the fat concentration in the sample, this methodology runs petroleum ether continuously through a sample to absorb and separate the fat. The samples used in this experiment weighed approximately $0.5 \mathrm{~g}$ and were extracted for 1 hour and 30 minutes. Lastly, the ashing was only executed on Experiment 1; by burning all organic matter at a temperature of $400^{\circ} \mathrm{C}$, the concentration of inorganic matter can be measured (920.153)(AOAC, 1990; Surendra et al., 2016). Chemical analyses were carried out in either duplicate or triplicate.

\section{Statistical analysis}

A one-way ANOVA was executed to determine significant differences between the fresh weight, dry weight, survival, protein percentage and fat percentage (SPSS, ver. 24). Furthermore, a bivariate correlation matrix was applied to examine the effect of the variables. The shape of the response surface for each trait was then visualized using non-parametric thinplate splines using the fields package in R-Studio. However, it should be noted that these are simply an aid to visualizing the surfaces and are not a direct output from the statistical models.

\section{Results}

\section{Experiment 1: Larval macronutrient composition}

Several observations can be made from the collected data (Table 2). Firstly, no obvious 'cutoff' point for the fat production was observed. However, the protein:fat ratio did rapidly increase during the first four days, after which, both protein and fat ratio appeared to stabilise. Secondly, the percentage dry-weight of the larvae increased from $18.1 \%$ to $38.7 \%$ over the course of 11 days (Figure 1). The protein and fat percentage appear to be negatively correlated as the increase of fat leads to a decrease of protein. Lastly, the ash percentage remained stable throughout the larval stage, until the pre-pupal stage. However, more data will be needed from the earlier time points the earlier days to validate this observation.

Table 2: An overview of the fresh weight (g), dry weight (g), protein (\%), fat (\%) and ash (\%) concentrations over the lifetime of the black soldier fly larvae. The * indicates that for the chemical analysis has only been done once, as not enough sample was collected for a duplicate.

\begin{tabular}{l|l|l|l|l|l|l|l} 
& $\begin{array}{l}\text { Fresh } \\
\text { weight } \\
(\mathrm{mg})\end{array}$ & $\begin{array}{l}\text { Dry } \\
\text { weight } \\
(\mathrm{mg})\end{array}$ & $\begin{array}{l}\text { Percentage } \\
\text { Dry } \\
\text { weight }\end{array}$ & $\begin{array}{l}\text { Protein } \\
(\%)\end{array}$ & Fat $(\%)$ & Ash (\%) & $\begin{array}{l}\text { Protein: } \\
\text { Fat Ratio }\end{array}$ \\
\hline 0 & 15.4 & 2.8 & 18.1 & 47.0 & $12.4^{*}$ & & 0.26 \\
24 & 19.8 & 5.0 & 25.1 & 33.3 & $22.6^{*}$ & & 0.68 \\
48 & 54.1 & 13.8 & 25.6 & 36.6 & 28.5 & & 0.78 \\
72 & 96.5 & 25.3 & 26.2 & 35.0 & 27.4 & & 0.78
\end{tabular}




\begin{tabular}{l|l|l|l|l|l|l|l}
96 & 123.7 & 38.3 & 31.0 & 31.8 & 35.2 & & 1.11 \\
117 & 151.0 & 49.6 & 32.8 & 31.4 & 34.7 & & 1.10 \\
141 & 141.0 & 43.3 & 30.7 & 32.0 & 35.1 & 9.3 & 1.10 \\
166 & 180.2 & 61.2 & 33.9 & 30.2 & 38.0 & 9.1 & 1.25 \\
192 & 199.6 & 67.6 & 33.8 & 29.6 & 39.4 & 9.1 & 1.33 \\
216 & 220.6 & 76.2 & 34.5 & 29.8 & 38.8 & 9.0 & 1.30 \\
240 & 225.3 & 80.5 & 35.7 & 29.0 & 38.9 & 9.1 & 1.34 \\
264 & 162.7 & 63.0 & 38.7 & 32.7 & 36.9 & 11.0 & 1.13
\end{tabular}

Figure 1: This graph presents the growth of the black soldier fly over the course of 11 days, the left-axis indicates the weight of the larvae $(\mathrm{mg})$ and the right-axis indicates the percentage of dry weight. The data used to create this graph is present in Table 2.

Experiment 2: Effect of protein and carbohydrates on the growth of black soldier fly larvae

The dataset is displayed in Figure 2 and Table 3. These data indicate that protein is more influential on the growth of the black soldier fly larvae than carbohydrate. This was further evidenced by the correlation matrix that indicated that the concentration of protein has a highly significant positive effect on the fresh and dry weight of the larvae (Pearson Correlation of: 0.638, 0.675; P-value: .000, .000, respectively). Whereas the effect of carbohydrates, although significant, was not as large of an influence on the fresh and dry weight of the larvae (Pearson Correlation of: $0.183,0.194$; P-value: .024, .017, respectively). The survival of the larvae was another good indicator of the weight, as the survival was significantly negatively-correlated with the fresh and dry weight (Pearson Correlation of: $-0.673,-0.554$; P-value: $.000, .000$, respectively). The protein concentration in the feed had a strong correlation with the percentage and concentration of protein (Pearson Correlation of: -0.470, 0.654; P-value: .000, .000, respectively) and fat in the larvae (Pearson Correlation of: 0.697 and 0.740; P-value: .000, .000, respectively). Whereas carbohydrates in the feed only had a small significant effect on the percentage of protein (Pearson Correlation of: -0.254; P-value: .022). Lastly, the birthweight of the larvae only had a significant effect on the dry weight (Pearson Correlation of: 0.204, Pvalue: .012).

Figure 2: This contour plot gives a visual representation of the effect of protein (x-axis) and carbohydrate (y-axis) on the fresh weight (left) and dry weight (right) of the black soldier fly larvae. The datapoints used to create this graph have been presented in Table 3. The colour regions represent a specific weight category as given in the legend of the figure. 
Table 3: The effect of varying concentrations of protein and carbohydrate on the average survival, fresh and dry weight and the protein and fat content of the larvae of the black soldier fly. A different number in the column indicates a significant difference. The protein and carbohydrate concentration of the respective treatments are based on the information given in table 1.

\begin{tabular}{|c|c|c|c|c|c|c|c|c|c|c|c|c|c|c|c|c|c|c|c|c|}
\hline \multirow{2}{*}{$\begin{array}{l}\text { Treatment } \\
\text { P1C1 }\end{array}$} & \multicolumn{4}{|c|}{ Fresh Weight (mg) } & \multicolumn{4}{|c|}{ Dry Weight (mg) } & \multicolumn{4}{|c|}{ Survival (\%) } & \multicolumn{4}{|c|}{ Protein $(\%)$} & \multicolumn{4}{|c|}{ Fat $(\%)$} \\
\hline & 154.77 & \pm & 21.5 & $\mathrm{~cd}$ & 47.35 & \pm & 5.8 & & $89.00 \%$ & \pm & $16.4 \%$ & $a b c$ & $36.36 \%$ & \pm & $0.9 \%$ & & $24.14 \%$ & \pm & $1.7 \%$ & $\mathrm{e}$ \\
\hline $\mathrm{P} 1 \mathrm{C} 2$ & 150.30 & \pm & 21.3 & de & 49.01 & \pm & 5.1 & ef & $82.40 \%$ & \pm & $20.3 \%$ & $\mathrm{~cd}$ & $36.35 \%$ & \pm & $0.9 \%$ & $\mathrm{bc}$ & $25.39 \%$ & \pm & $3.4 \%$ & $\mathrm{e}$ \\
\hline $\mathrm{P} 1 \mathrm{C} 3$ & 150.98 & \pm & 15.7 & de & 47.44 & \pm & 6.8 & $\mathrm{f}$ & $94.80 \%$ & \pm & $8.3 \%$ & $a b$ & $35.93 \%$ & \pm & $1.0 \%$ & cde & $26.53 \%$ & \pm & $1.8 \%$ & cde \\
\hline $\mathrm{P} 1 \mathrm{C} 4$ & 154.98 & \pm & 16.5 & $\mathrm{~cd}$ & 49.02 & \pm & 9.1 & ef & $95.00 \%$ & \pm & $7.0 \%$ & $\mathrm{ab}$ & $35.80 \%$ & \pm & $1.0 \%$ & cde & $26.14 \%$ & \pm & $1.4 \%$ & de \\
\hline $\mathrm{P} 1 \mathrm{C} 5$ & 148.16 & \pm & 15.8 & de & 46.58 & \pm & 5.2 & fg & $99.60 \%$ & \pm & $0.8 \%$ & $\mathrm{a}$ & $34.90 \%$ & \pm & $1.1 \%$ & def & $24.54 \%$ & \pm & $4.4 \%$ & $\mathrm{e}$ \\
\hline $\mathrm{P} 2 \mathrm{C} 1$ & 145.66 & \pm & 14.7 & de & 46.36 & \pm & 5.4 & fg & $87.80 \%$ & \pm & $20.2 \%$ & $\mathrm{bc}$ & $37.75 \%$ & \pm & $0.9 \%$ & $\mathrm{a}$ & $25.51 \%$ & \pm & $1.9 \%$ & $\mathrm{e}$ \\
\hline $\mathrm{P} 2 \mathrm{C} 2$ & 133.89 & \pm & 14.1 & $\mathrm{e}$ & 41.99 & \pm & 6.3 & $\mathrm{~g}$ & $99.00 \%$ & \pm & $1.4 \%$ & $a b$ & $37.96 \%$ & \pm & $1.3 \%$ & $\mathrm{a}$ & $23.85 \%$ & \pm & $2.4 \%$ & e \\
\hline $\mathrm{P} 2 \mathrm{C} 3$ & 154.69 & \pm & 18.5 & dcd & 33.53 & \pm & 4.7 & $\mathrm{~h}$ & $90.80 \%$ & \pm & $18.4 \%$ & $a b c$ & $37.58 \%$ & \pm & $0.5 \%$ & $a b$ & $23.93 \%$ & \pm & $3.4 \%$ & $\mathrm{e}$ \\
\hline P3C3 & 165.24 & \pm & 12.8 & bcd & 54.36 & \pm & 5.8 & de & $98.00 \%$ & \pm & $3.1 \%$ & $a b$ & $36.00 \%$ & \pm & $1.2 \%$ & $\mathrm{~cd}$ & $29.24 \%$ & \pm & $2.4 \%$ & bcd \\
\hline P3C4 & 169.06 & \pm & 14.8 & $\mathrm{bc}$ & 56.44 & \pm & 6.5 & $\mathrm{~cd}$ & $96.80 \%$ & \pm & $4.3 \%$ & $a b$ & $36.07 \%$ & \pm & $2.1 \%$ & $\mathrm{~cd}$ & $30.47 \%$ & \pm & $3.2 \%$ & $a b$ \\
\hline P3C5 & 171.37 & \pm & 17.7 & $\mathrm{bc}$ & 54.40 & \pm & 6.9 & de & $94.20 \%$ & \pm & $11.7 \%$ & $a b$ & $36.33 \%$ & \pm & $1.1 \%$ & $\mathrm{bc}$ & $29.60 \%$ & \pm & $1.7 \%$ & $a b c$ \\
\hline $\mathrm{P} 4 \mathrm{C} 1$ & 194.68 & \pm & 28.4 & $\mathrm{a}$ & 62.35 & \pm & 5.7 & $a b$ & $55.60 \%$ & \pm & $14.4 \%$ & $\mathrm{f}$ & $34.15 \%$ & \pm & $0.8 \%$ & $\mathrm{~g}$ & $32.47 \%$ & \pm & $0.9 \%$ & $\mathrm{a}$ \\
\hline $\mathrm{P} 4 \mathrm{C} 2$ & 176.48 & \pm & 23.6 & $\mathrm{a}$ & 59.00 & \pm & 6.9 & bcd & $74.60 \%$ & \pm & $18.1 \%$ & de & $34.37 \%$ & \pm & $0.8 \%$ & $\mathrm{~g}$ & $30.57 \%$ & \pm & $1.6 \%$ & $a b$ \\
\hline $\mathrm{P} 4 \mathrm{C} 3$ & 199.60 & \pm & 22.8 & $\mathrm{a}$ & 65.61 & \pm & 6.9 & $\mathrm{a}$ & $70.40 \%$ & \pm & $13.1 \%$ & $\mathrm{e}$ & $34.62 \%$ & \pm & $0.3 \%$ & efg & $31.13 \%$ & \pm & $3.5 \%$ & $a b$ \\
\hline $\mathrm{P} 4 \mathrm{C} 4$ & 184.80 & \pm & 11.6 & $a b$ & 61.32 & \pm & 2.3 & $a b c$ & $80.20 \%$ & \pm & $12.1 \%$ & cde & $34.69 \%$ & \pm & $0.8 \%$ & efg & $30.13 \%$ & \pm & $1.8 \%$ & $a b$ \\
\hline $\mathrm{P} 4 \mathrm{C} 5$ & 195.46 & \pm & 25.9 & $\mathrm{a}$ & 63.89 & \pm & 4.0 & $\mathrm{ab}$ & $78.60 \%$ & \pm & $14.1 \%$ & cde & $34.16 \%$ & \pm & $0.4 \%$ & $\mathrm{fg}$ & $31.70 \%$ & \pm & $1.1 \%$ & $a b$ \\
\hline
\end{tabular}




\section{Discussion}

Experiment 1 showed that larvae have proportionally more protein in their earlier instars, and accumulate fat until a point where they grow similarly in protein and fat. These finding are like a study performed by Liu et al. (2017) who also found a lower percentage of fat in the early instars. Liu et al., (2017) had a similar concentration of protein as this study. However, the fat percentage is generally $10 \%$ lower, this could perhaps be caused by the different strain of black soldier flies. The results for late-instar larvae are supported by the literature. These previous studies found protein concentrations such as 30.46-33.32\% (original numbers were converted with protein factor 4.76 instead of 6.25)., and fat percentages of 30- 35\% (Liu et al., 2017; Newton et al., 2005; Nyakeri et al., 2017; Sheppard et al., 1994; St-Hilaire et al., 2007; Tschirner and Simon, 2015). Interestingly, the ash concentration throughout the sampling period was very stable, at around $9.2 \%$ and increased to $11 \%$ at the pre-pupal stage. These numbers are comparable to the study executed by Liu et al. (2017), but lower than in other studies, which found 15-16.6\% of ash (Newton et al. (2005); Nyakeri et al. (2017); St-Hilaire et al. (2007). Again, this might be due to the difference in feeding substrate of the black soldier fly larvae: both Newton et al. (2005) and St-Hilaire et al. (2007) used manure to rear black soldier fly larvae, and Nyakeri et al. (2017) used fruit and vegetable waste, whereas in our experiment larvae were fed chickenfeed. The control substrate from Tschirner and Simon (2015), containing a wide spectrum of cereal leftovers such as broken pellets, spilled grains and grinding dust, would be most comparable to the chickenfeed diet that was used. Tschirner and Simon (2015) found larvae to be around $37.2 \%$ dry-weight, which is comparable to the larval dry weight in this study.

The results from the second experiment indicate that carbohydrate only have a small contribution to growth of the larvae, especially when compared to the importance of dietary protein. A previous study by Cammack and Tomberlin (2017) suggests that larvae should be reared on a balanced diet of $21 \%$ protein and $21 \%$ carbohydrates, in that treatment each larvae had approximately $0.24 \mathrm{~g}$ of protein and carbohydrate and weighed around $80 \mathrm{mg}$ as a prepupae. For comparison the larvae in this study were fed between $0.041 \mathrm{~g}$ and $0.076 \mathrm{~g}$ of protein and between 0.115 and $0.178 \mathrm{~g}$ of carbohydrate depending on the treatment and weighed between $133.9 \mathrm{mg}$ and $199.6 \mathrm{mg}$. Although, this is not a good comparison due to the difference in instar that was weighed, it does further highlight the importance of understanding the impact of different amino acid profiles as larval growth in insects is affected by the variation in amino acids (Davis, 1975). A number of studies suggest that black soldier fly larvae do not grow as well on animal-based protein as they would on plant-based protein (Cammack and Tomberlin, 2017; Gobbi et al., 2013; Nguyen et al., 2015; Nguyen et al., 2013; Nyakeri et al., 2017). However, this is still an under-studied area as the whey protein used in this study would qualify as an animal protein and it is thought that not all plant-based feeds provide enough protein. For example, a study by Mohd-Noor et al. (2017) used coconut endosperm as a feed, and the low protein concentration (3-4\%) in the coconut endosperm most likely prohibited the growth of the larvae. Another example would be the dried sugar beet pulp from the study of Tschirner and Simon (2015), this feeding substrate only had $8.5 \%$ protein and produced the lightest larvae of their study.

According to the correlation matrix the percentage of dietary protein was negatively correlated with the percentage of protein in the larvae, as the heavier larvae would produce more fat than the lighter ones and decrease the percentage of protein. The negative correlation of the fresh and dry weight with the survival of the larvae is understandable as well: the fewer larvae present in the substrate, the more nutrition is available to the remaining larvae. 


\section{Conclusion}

To conclude, the macro nutritional composition of black soldier fly larvae does not greatly change over their life history, with the exception of freshly hatched larvae and the pre-pupal stage. The younger larvae showed higher percentage of protein compared to the older larvae. The pre-pupal stage larvae lost weight compared to late instar larvae, as well as exhibiting a higher percentage of ash and dry-weight.

The hypothesis regarding the influence of dietary protein on larval composition can be accepted, as the dietary protein concentration increased the fresh- and dry weight. The hypothesis with regard to the influence of dietary carbohydrate can be rejected, as the dietary carbohydrate did not have a significant effect on either the fat percentage or fat concentration in the black soldier fly larvae.

For future studies, it can be recommended to examine higher concentrations of protein to find the maximum concentration of protein, as well as examining the effect of other nutrients (e.g. micronutrients) and minerals on the growth and composition of black soldier fly larvae. Lastly, a similar experiment to Davis (1975) would allow for more accurate understanding of the protein requirement of the black soldier fly.

\section{References}

AOAC, 1990. Official Methods of Analysis of the Association of Official Analytical Chemists, 2. Association of Official Analytical Chemists, Inc., Arlington, Virginia, USA.

Barroso, F.G., Sánchez-Muros, M.-J., Segura, M., Morote, E., Torres, A., Ramos, R. and Guil, J.-L., 2017. Insects as food: Enrichment of larvae of Hermetia illucens with omega 3 fatty acids by means of dietary modifications. Journal of Food Composition and Analysis 62: 8-13.

Burtle, G., Newton, G. and Sheppard, D., 2012. Mass production of black soldier fly prepupae for aquaculture diets. Aquaculture.

Cammack, J.A. and Tomberlin, J.K., 2017. The Impact of Diet Protein and Carbohydrate on Select LifeHistory Traits of The Black Soldier Fly Hermetia illucens (L.) (Diptera: Stratiomyidae). Insects 8.

Choi, W.-H., Yun, J.-H., Chu, J.-P. and Chu, K.-B., 2012. Antibacterial effect of extracts ofHermetia illucens(Diptera: Stratiomyidae) larvae against Gram-negative bacteria. Entomological Research 42: 219-226.

Choi, W.H. and Jiang, M., 2014. Evaluation of antibacterial activity of hexanedioic acid isolated from Hermetia illucens larvae. Journal of Applied Biomedicine 12: 179-189.

Cummins, V.C., Rawles, S.D., Thompson, K.R., Velasquez, A., Kobayashi, Y., Hager, J. and Webster, C.D., 2017. Evaluation of black soldier fly (Hermetia illucens) larvae meal as partial or total replacement of marine fish meal in practical diets for Pacific white shrimp ( Litopenaeus vannamei ). Aquaculture 473: 337-344.

Davis, G.R.F., 1975. Essential Dietary Amino Acids for Growth of Larvae of the Yellow Mealworm, Tenebrio molitor $L$. The Journal of Nutrition 105: 1071-1075.

Elhag, O., Zhou, D., Song, Q., Soomro, A.A., Cai, M., Zheng, L., Yu, Z. and Zhang, J., 2017. Screening, Expression, Purification and Functional Characterization of Novel Antimicrobial Peptide Genes from Hermetia illucens (L.). PLoS One 12: e0169582.

Eriksson, R. and Andersson, J., 2010. Elements of Ecological Economics.

Gahukar, R.T., 2011. Entomophagy and human food security. International Journal of Tropical Insect Science 31: 129-144.

Gobbi, P., Martínez-Sánchez, A. and Rojo, S., 2013. The effects of larval diet on adult life-history traits on the black soldier fly, Hermetia illucens (Diptera: Stratiomyidae). European Journal of Entomology 11: 461-468.

Janssen, R.H., Vincken, J.P., van den Broek, L.A., Fogliano, V. and Lakemond, C.M., 2017. Nitrogen-toProtein Conversion Factors for Three Edible Insects: Tenebrio molitor, Alphitobius diaperinus, and Hermetia illucens. J Agric Food Chem 65: 2275-2278. 
Kroeckel, S., Harjes, A.G.E., Roth, I., Katz, H., Wuertz, S., Susenbeth, A. and Schulz, C., 2012. When a turbot catches a fly: Evaluation of a pre-pupae meal of the Black Soldier Fly (Hermetia illucens) as fish meal substitute - Growth performance and chitin degradation in juvenile turbot (Psetta maxima). Aquaculture 364-365: 345-352.

Lalander, C., Diener, S., Magri, M.E., Zurbrugg, C., Lindstrom, A. and Vinneras, B., 2013. Faecal sludge management with the larvae of the black soldier fly (Hermetia illucens)--from a hygiene aspect. Sci Total Environ 458-460: 312-318.

Liu, X., Chen, X., Wang, H., Yang, Q., Ur Rehman, K., Li, W., Cai, M., Li, Q., Mazza, L., Zhang, J., Yu, Z. and Zheng, L., 2017. Dynamic changes of nutrient composition throughout the entire life cycle of black soldier fly. PLoS One 12: e0182601.

Lord, W.D., Goff, M.L., Adkins, T.R. and Haskell, N.H., 1994. The Black Soldier FlyHermetia illucens(Diptera: Stratiomyidae) As a Potential Measure of Human Postmortem Interval: Observations and Case Histories. Journal of Forensic Sciences 39.

Mohd-Noor, S.-N., Wong, C.-Y., Lim, J.-W., Mah-Hussin, M.-I.-A., Uemura, Y., Lam, M.-K., Ramli, A., Bashir, M.J.K. and Tham, L., 2017. Optimization of self-fermented period of waste coconut endosperm destined to feed black soldier fly larvae in enhancing the lipid and protein yields. Renewable Energy 111: 646-654.

Nadeau, L., Nadeau, I., Franklin, F. and Dunkel, F., 2015. The potential for entomophagy to address undernutrition. Ecol Food Nutr 54: 200-208.

Newton, G., Sheppard, D., Watson, D.W., Burtle, G.J., Dove, C.R., Tomberlin, J.K. and Thelen, E.E., 2005. The black soldier fly, hermetia illucens, as a manure management/ resource recovery tool. Symposium on the state of the science of Animal manure and waste management.

Nguyen, T.T., Tomberlin, J.K. and Vanlaerhoven, S., 2015. Ability of Black Soldier Fly (Diptera: Stratiomyidae) Larvae to Recycle Food Waste. Environ Entomol 44: 406-410.

Nguyen, T.T.X., Tomberlin, J.K. and Vanlaerhoven, S., 2013. Influence of Resources onHermetia illucens (Diptera: Stratiomyidae) Larval Development. Journal of Medical Entomology 50: 898-906.

Nyakeri, E.M., Ogola, H.J., Ayieko, M.A. and Amimo, F.A., 2017. An open system for farming black soldier fly larvae as a source of proteins for smallscale poultry and fish production. Journal of Insects as Food and Feed 3: 51-56.

Oonincx, D.G., van Broekhoven, S., van Huis, A. and van Loon, J.J., 2015. Feed Conversion, Survival and Development, and Composition of Four Insect Species on Diets Composed of Food ByProducts. PLoS One 10: e0144601.

Park, S.-I., Chang, B.S. and Yoe, S.M., 2014. Detection of antimicrobial substances from larvae of the black soldier fly, Hermetia illucens(Diptera: Stratiomyidae). Entomological Research 44: 58-64.

Pujol-Luz, J.R., Francez, P.A., Ururahy-Rodrigues, A. and Constantino, R., 2008. The black soldier-fly, Hermetia illucens (Diptera, Stratiomyidae), used to estimate the postmortem interval in a case in Amapa State, Brazil. J Forensic Sci 53: 476-478.

Sheppard, D.C., Newton, G.L., Thompson, S.A. and Savage, S., 1994. A value added manure management system using the black soldier fly. Bioresource Technology 50: 275-279.

St-Hilaire, S., Cranhill, K., McGuire, M.A., Mosley, E.E., Tomberlin, J.K., Newton, L., Sealey, W., Sheppard, C. and Irving, S., 2007. Fish Offal Recycling by the black soldier fly produces a foodstuff high in omega-3 fatty acids. Journal of the World Aquaculture Society 38.

Surendra, K.C., Olivier, R., Tomberlin, J.K., Jha, R. and Khanal, S.K., 2016. Bioconversion of organic wastes into biodiesel and animal feed via insect farming. Renewable Energy 98: 197-202.

Tschirner, M. and Simon, A., 2015. Influence of different growing substrates and processing on the nutrient composition of black soldier fly larvae destined for animal feed. Journal of Insects as Food and Feed 1: 249-259.

Zhou, F., Tomberlin, J.K., Zheng, L., Yu, Z. and Zhang, J., 2013. Developmental and Waste Reduction Plasticity of Three Black Soldier Fly Strains (Diptera: Stratiomyidae) Raised on Different Livestock Manures. Journal of Medical Entomology 50: 1224-1230. 